\title{
Where were the northern elephant seals? Holocene archaeology and biogeography of Mirounga angustirostris
}

\author{
Torben C. Rick,' Robert L. DeLong, ${ }^{2}$ Jon M. Erlandson, ${ }^{3}$ \\ Todd J. Braje, ${ }^{4}$ Terry L. Jones, ${ }^{5}$ Jeanne E. Arnold, ${ }^{6}$ \\ Matthew R. Des Lauriers, ${ }^{7}$ William R. Hildebrandt, ${ }^{8}$ \\ Douglas J. Kennett, ${ }^{3}$ René L. Vellanoweth ${ }^{9}$ and Thomas A. Wake ${ }^{6}$
}

\begin{abstract}
Driven to the brink of extinction during the nineteenth century commercial fur and oil trade, northern elephant seal (NES, Mirounga angustirostris) populations now exceed 100000 animals in the northeast Pacific from Alaska to Baja California. Because little is known about the biogeography and ecology of NES prior to the mid-nineteenth century, we synthesize and analyze the occurrence of NES remains in North American archaeological sites. Comparing these archaeological data with modern biogeographical, genetic, and behavioral data, we provide a trans-Holocene perspective on NES distribution and abundance. Compared with other pinnipeds, NES bones are relatively rare throughout the Holocene, even in California where they currently breed in large numbers. Low numbers of NES north of California match contemporary NES distribution, but extremely low occurrences in California suggest their abundance in this area was very different during the Holocene than today. We propose four hypotheses to explain this discrepancy, concluding that ancient human settlement and other activities may have displaced NES from many of their preferred modern habitats during much of the Holocene.
\end{abstract}

\section{Keywords}

historical ecology, human-environmental interactions, marine conservation, Pacific Coast, pinniped, Phocidae

\section{Introduction}

Northern elephant seals (NES hereafter, Mirounga angustirostris) were nearly driven to extinction by commercial and recreational hunters during the nineteenth century fur and oil trade (Scammon, 1874: 119; Stewart et al., 1994). Despite limited genetic diversity (Bonnell and Selander, 1972; Weber et al., 2000, 2004), NES along North America's Pacific Coast are now thriving, with some 124000 animals in the California stock alone (Carretta et al., 2009: 28). The recovery of NES populations is one of the success stories of marine conservation, demonstrating resilience despite decades of intensive slaughter (Stewart et al., 1994). Because of rapid decimation from commercial hunting, little is known about NES prior to the mid-nineteenth century, however, leaving a substantial gap in our understanding of their natural history, biogeography, and historical ecology.

In this paper, we synthesize all known occurrences of NES in northeastern Pacific Coast archaeological sites, including analysis of previously reported materials and new unpublished data (Figure 1). Other archaeological studies of seal and sea lion (pinniped) remains from Pacific Coast archaeological sites have noted the dearth of NES relative to other pinnipeds (e.g. Hildebrandt and Jones, 2002; Lyman, 2011). Our study is the first to focus solely on NES and to place these data within the context of ancient DNA analyses and modern behavioral data. Similar to earlier archaeological studies of northeastern Pacific pinnipeds (Braje et al., 2011; Etnier, 2007; Gifford-Gonzalez et al., 2005; Hildebrandt and Jones, 1992, 2002; Lyman, 1988, 2003; Moss et al., 2006;
Newsome et al., 2007; Rick et al., 2009), our goal is to document long-term trends in NES biogeography and abundance that can help inform their contemporary status.

\section{Historical and modern NES distribution and behavior}

NES are the largest pinnipeds in the northeastern Pacific, with males weighing up to $2300 \mathrm{~kg}$ and females $800 \mathrm{~kg}$ (Stewart and Huber, 1993). Formally described as a species by Gill (1866), NES were thought to be extinct by the late 1870 s (Townsend,

'Smithsonian Institution, USA

${ }^{2}$ Alaska Fisheries Science Center, USA

${ }^{3}$ University of Oregon, USA

${ }^{4}$ San Diego State University, USA

${ }^{5}$ California Polytechnic State University, USA

${ }^{6}$ University of California, Los Angeles, USA

${ }^{7}$ California State University Northridge, USA

${ }^{8}$ Far Western Anthropological Research Group, USA

${ }^{9}$ California State University Los Angeles, USA

\section{Corresponding author:}

Torben C. Rick, Program in Human Ecology and Archaeobiology, Department of Anthropology, National Museum of Natural History, Smithsonian Institution, Washington DC 200I3-70I2, USA.

Email: rickt@si.edu 


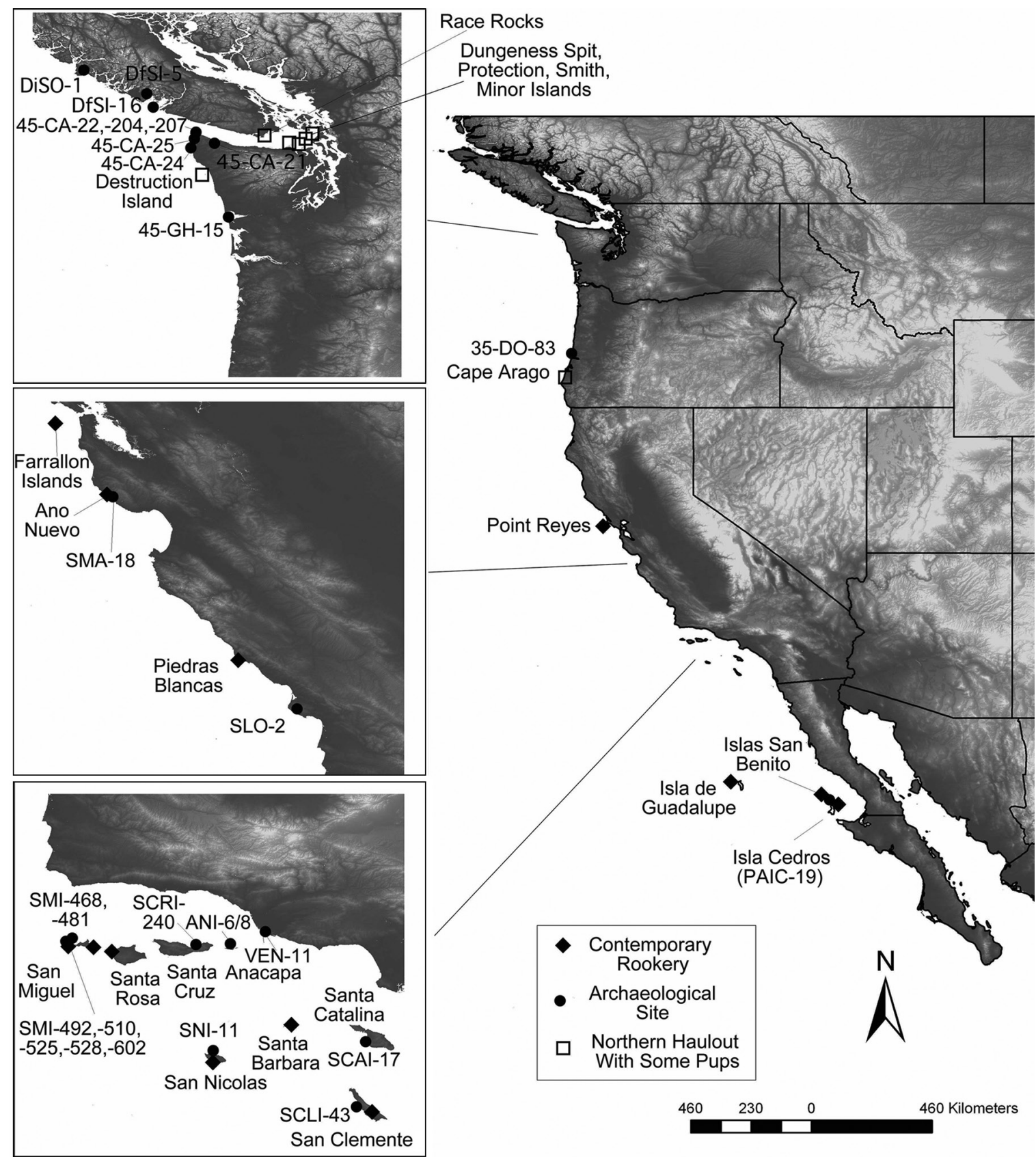

Figure I. Western North America with inset of Channel Islands, central California, and Washington/Southern British Columbia showing the location of archaeological sites with NES remains and modern breeding colonies

1885) until a series of expeditions found and killed individuals on Isla de Guadalupe between 1880 and 1884 (Stewart et al., 1994: 30-31). They were again thought to be extinct until 1892 when Townsend and Anthony identified nine animals on Isla de Guadalupe and killed seven of them for the Smithsonian Institution's collections (Anthony, 1924; Townsend, 1912). Through 1911 NES populations increased and 'museum collectors continued to kill them' (Stewart et al., 1994: 32), including 4 in 1904, 14 of 40 in 1907, and 10 of $\sim 135$ in 1911 (see also Bartholomew and Hubbs, 1960).

The population continued to grow as NES established breeding populations on San Miguel, San Nicolas, and Santa Barbara islands by the 1950s, at Año Nuevo Island in 1961, at the Farallones in 1972, on Point Año Nuevo in 1975, at Point Reyes in 1981, and on Santa Rosa Island in 1985 (Stewart and Huber, 1993; Stewart et al., 1994). The largest mainland colony was established in 1991 on the extensive beaches south of Point Piedras Blancas in central California (Brian Hatfield, personal communication, 2009). Small breeding colonies, limited in size by the amount of rookery and haul-out habitat, now occur at Cape Arago, Oregon (Hodder et al., 1998). A few pups also have been born in the Strait of Juan de Fuca, on Protection and Smith-Minor islands and Dungeness Spit in Washington (Jeffries et al., 2000) and at Race Rocks in British Columbia (Steve Jeffries, personal communication, 2009). Since not all age and sex classes are ashore at the same time, estimating contemporary NES populations is difficult. Carretta et al. (2007: 28) estimated that the California NES population was around 101000 in 2001 and by 2005 had grown to 124000 (Carretta et al., 2009: 28). There is an additional population of NES breeding on islands of the Pacific Coast of Baja California, Mexico. The Mexico population was estimated to number about 32000 animals in 1992 (Stewart et al., 1994), and 
in 2003 Gallo-Reynoso et al. (2005: 181) estimated the population on Isla de Guadalupe at 14965.

Despite their large size, several behaviors make NES susceptible to human hunting, especially females and young individuals. Although their annual migrations span some 18 000-21 $000 \mathrm{~km}$ (Stewart and DeLong, 1993), NES come ashore two to three times yearly to breed and molt (Stewart and Huber, 1993). NES breed on land in reproductive territories featuring one or more large bull(s) and an aggregation of females. Pups, generally born in January and February, are nursed for about 30 days when they are weaned and left helpless on land for $<4$ months while they develop swimming skills. The weaned pups would have been the age group most susceptible to hunting by early humans. NES yearlings, immatures and adults also spend most of their molt period, lasting $\sim 4$ to 6 weeks in spring/summer, on land. Nonpregnant females and young individuals may haul-out again briefly in October (Stewart and Huber, 1993). Unlike Pacific Coast otariids, NES prefer sand and gravel beaches, which they use for thermoregulation, and do not use rocky areas for haul-outs or breeding. This significant time spent ashore, pups left alone, and propensity to use sand and gravel beaches made NES susceptible to human hunting during the historic fur and oil trade and prehistorically for Native American subsistence. Vulnerability to large non-human predators (grizzly bears, mountain lions, etc.) may have restricted the onshore activity of NES primarily to island settings (Erlandson et al., 1998) or isolated mainland locations.

Assuming humans would have hunted/scavenged prehistoric NES and other pinnipeds in direct proportion to their natural abundance, we can predict the following from modern and historical records: (1) Holocene NES should occur in archaeological sites from Baja California to Alaska; (2) the greatest numbers of archaeological NES specimens should come from Baja and Alta California where $>124000$ NES now breed and reside; (3) in archaeological sites on the offshore islands of California, NES remains should be one of the most abundant of the six pinniped species documented in the area; and (4) since NES are found mostly offshore in northern waters (Stewart and DeLong, 1993), archaeological specimens north of California should be comparatively rare.

\section{Materials and methods}

Along with our own analyses of NES remains from California archaeological sites, we systematically searched the literature for reports of archaeological NES remains recovered from Baja California to Alaska. To determine more specific age and sex data, DeLong and Rick also re-analyzed collections from CA-ANI-6 and CA-ANI-8 on Anacapa Island (Sanderfur, 1978; Walker, 1978), CA-SMI-481 and CA-SMI-525 on San Miguel Island (Rick, 2007; Walker and Craig, 1979), and CA-SCLI-43B on San Clemente Island (Porcasi et al., 2000). These analyses resulted in some slight differences between our data and the original studies. We were unable to relocate NES bones from CA-VEN-11 (Lyon, 1937), so we relied on the data presented in the original report. In our experience working with pinniped remains from the Channel Islands, NES - especially their cranial remains, teeth, and long bones - are relatively easy to distinguish from those of other northeastern Pacific pinnipeds, resulting in a fairly high degree of confidence in their identification.
We report archaeological NES as the number of identified specimens (NISP), a total count of all bones, teeth, or fragments identified from each archaeological site, relying on this measure to evaluate ancient NES abundance (Lyman, 2008). To investigate NES abundance in ancient and modern times we constructed an abundance index that quantifies archaeological NES remains as $\sum$ NES NISP/ $\sum$ Total Identified Pinniped NISP for all samples with greater than 30 NISP. To quantify modern abundance, we relied on population estimates from San Miguel Island in 1997 (DeLong and Melin, 2002) and the California stock (the US stock estimate was used for California sea lion abundance) in 2005 (Carretta et al., 2009), where $\sum$ NES Population/ $\sum$ Total Pinniped Population from San Miguel Island or California. Because we only have one bone from Baja California we have not included estimates for Mexico.

Although rarely reported, all available age at death and sex data are presented to help evaluate the composition and structure of ancient NES populations and the possibility of selectivity in human harvest strategies. The antiquity of the specimens presented here was estimated from radiocarbon dates obtained for each archaeological site. In some cases, it was difficult to determine how closely associated radiocarbon dates are with NES remains, especially for those recovered from surface contexts. In most instances, we provide age ranges for entire sites or components rather than for specific bones.

\section{Results}

Our survey of archaeological data from western North America revealed just 28 archaeological sites with NES bones, ranging from Isla Cedros, Baja California to southern British Columbia (Table 1). A total of only 96 NES bones was identified. In comparison, the remains of Guadalupe fur seals (Arctocephalus townsendi), which are rare in California waters today, are common in prehistoric Alta California where nearly 3500 specimens have been reported from 60 sites spanning 8000 years (Rick et al., 2009). Most of the NES bones and teeth were from the Channel Islands, where 13 sites from six of the eight islands contain NES remains. Five additional NES bones were recovered from a nineteenth to twentieth century bald eagle nest on San Miguel Island, indicating NES presence at this time (Collins et al., 2005). Along the mainland coast of California, only three sites have produced NES remains, including 21 specimens from CA-VEN-11 at Point Mugu, where they represent just $1 \%$ of the total pinniped NISP. A single NES bone was also identified from CA-SMA-18 at Point Año Nuevo and another was recovered from CA-SLO-2 at Diablo Canyon.

To the south, PAIC-19 on Baja California's Isla Cedros produced one NES bone. NES occur in 11 archaeological sites north of California, including three NES bones from 35-DO-83 in Oregon, which produced abundant remains of northern fur seals ( $\mathrm{Cal}$ lorhinus ursinus) and Steller sea lions (Eumetopias jubatus) (Lyman, 1988). Seven sites in Washington have produced NES bones, but these generally constitute less than $1 \%$ of each assemblage. Finally, three sites in southern British Columbia each produced one NES bone, all of which are from the west coast of Vancouver Island, a pattern comparable with the recent distribution of NES (Campbell, 1987).

The geographic distribution of these sites suggests that ancient NES had a geographic range similar to today, from approximately 
Table I. Northern elephant seal remains in northeastern Pacific Coast archaeological sites

\begin{tabular}{|c|c|c|c|c|c|}
\hline Site number ${ }^{\mathrm{a}}$ & Age (cal. BP) & Count & $\mathrm{MNI}^{\mathrm{b}}$ & Comment & References \\
\hline \multicolumn{6}{|l|}{ Baja California } \\
\hline PAIC-19 (Isla Cedros) & $410-290$ & I & 1 & Juvenile vertebra & Des Lauriers (2005); this article \\
\hline \multicolumn{6}{|l|}{ California } \\
\hline $\begin{array}{l}\text { CA-ANI-6 (Anacapa } \\
\text { Island) }\end{array}$ & $630-550$ & I & 1 & $\begin{array}{l}\text { Astragulus bone in small assemblage with Guadalupe fur } \\
\text { and harbor seals }\end{array}$ & Walker (1978) \\
\hline $\begin{array}{l}\text { CA-ANI-8 (Anacapa } \\
\text { Island) }\end{array}$ & $5020-540$ & I & 1 & $\begin{array}{l}\text { Immature female maxilla with California sea lion, } \\
\text { Guadalupe fur seal, and harbor seal }\end{array}$ & Sanderfur (1978) \\
\hline $\begin{array}{l}\text { CA-SCAI-I7 (Santa } \\
\text { Catalina Island) }\end{array}$ & \multicolumn{4}{|c|}{ Catalina Island) } & Porcasi (2002) \\
\hline $\begin{array}{l}\text { CA-SCLI-43B (San } \\
\text { Clemente Island) }\end{array}$ & Late Holocene & 6 & 4 & $\begin{array}{l}\text { Fragmentary cranial elements and metacarpals constitute } \\
<5 \% \text { of pinniped NISP }\end{array}$ & Porcasi et al. (2000) \\
\hline $\begin{array}{l}\text { CA-SCRI-240 (Santa } \\
\text { Cruz Island) }\end{array}$ & Historic & 1 & 1 & $\begin{array}{l}\text { Pup mandible from possible feasting context with } \\
\text { swordfish and other species }\end{array}$ & This paper \\
\hline $\begin{array}{l}\text { CA-SLO-2 (Diablo } \\
\text { Canyon) }\end{array}$ & $500-200$ & 1 & 1 & $\begin{array}{l}<1 \% \text { of pinniped NISP; harbor seals and California sea } \\
\text { lions dominant }\end{array}$ & Jones et al. (2008) \\
\hline $\begin{array}{l}\text { CA-SMA-18 (Point Año } \\
\text { Nuevo) }\end{array}$ & $1480-1070$ & 1 & 1 & $\begin{array}{l}\text { I bone from Point Año Nuevo; assemblage dominated by } \\
\text { northern fur seals and otariids }\end{array}$ & $\begin{array}{l}\text { Gifford-Gonzalez and Sunseri } \\
\text { (2009) }\end{array}$ \\
\hline $\begin{array}{l}\text { CA-SMI-468 (San } \\
\text { Miguel Island) }\end{array}$ & $910-720$ & 1 & 1 & $\begin{array}{l}\text { I of only } 3 \text { pinniped species identified in small } \\
\text { assemblage. }\end{array}$ & Rick (2007) \\
\hline $\begin{array}{l}\text { CA-SMI-48I (San } \\
\text { Miguel Island) }\end{array}$ & $5980-960$ & 4 & 3 & $\begin{array}{l}\sim \text { I-3\% of pinniped NISP. I bone and I MNI from Walker } \\
\text { and Snethkamp; I adult female mandible (all of these } \\
\text { are } \sim 1280-960 \text { cal BP); I adult female maxilla and I adult } \\
\text { female canine from } \sim 6000 \text { yr old shell midden }\end{array}$ & $\begin{array}{l}\text { Walker and Snethkamp } \\
\text { (1984); Colten (2002); } \\
\text { Rick (2007);Vellanoweth } \\
\text { et al. (2006) }\end{array}$ \\
\hline $\begin{array}{l}\text { CA-SMI-492 (San } \\
\text { Miguel Island) }\end{array}$ & $5580-1250$ & I & 1 & I\% of total pinniped NISP identified to species & $\begin{array}{l}\text { Walker and Snethkamp } \\
\text { (1984); Colten (2002) }\end{array}$ \\
\hline $\begin{array}{l}\text { CA-SMI-510 (San } \\
\text { Miguel Island) }\end{array}$ & $1260-1130$ & I & 1 & $4 \%$ of total pinniped NISP identified to species & $\begin{array}{l}\text { Walker and Snethkamp } \\
\text { (1984); Colten (2002) }\end{array}$ \\
\hline $\begin{array}{l}\text { CA-SMI-525 (San } \\
\text { Miguel Island) }\end{array}$ & $3230-520$ & 17 & 5 & $\begin{array}{l}\text { Small portion of assemblage dominated by Guadalupe fur } \\
\text { seals, including } 3 \text { juvenile males and I female }\end{array}$ & $\begin{array}{l}\text { Walker and Craig (1979); } \\
\text { Walker (1978);This paper }\end{array}$ \\
\hline $\begin{array}{l}\text { CA-SMI-528 (San } \\
\text { Miguel Island) }\end{array}$ & $|570-1| 20$ & I & 1 & $\begin{array}{l}<1 \% \text { of pinniped assemblage, with Guadalupe fur seals } \\
\text { most common. Possible adult female }\end{array}$ & Walker et al. (2002) \\
\hline $\begin{array}{l}\text { CA-SMI-602 (San } \\
\text { Miguel Island) }\end{array}$ & 540-Historic & 9 & 4 & $\begin{array}{l}\text { Limited part of the assemblage dominated by Guadalupe } \\
\text { fur seals. Includes two juveniles, a pup, and }<1 \text { year old }\end{array}$ & $\begin{array}{l}\text { This paper; Walker et al., } \\
(2002)\end{array}$ \\
\hline $\begin{array}{l}\text { CA-SNI-II (San } \\
\text { Nicolas Island) }\end{array}$ & $6980-510$ & 14 & 4 & $2 \%$ of total pinniped bones identified to species & Bleitz (1993) \\
\hline $\begin{array}{l}\text { CA-VEN-II (Point } \\
\text { Mugu) }\end{array}$ & Historic & 21 & 5 & $\begin{array}{l}\text { I\% of total NISP for pinnipeds and sea otters. Sex not } \\
\text { determined, but seven adult and } 14 \text { juvenile bones }\end{array}$ & Lyon (1937) \\
\hline \multicolumn{6}{|l|}{ Oregon } \\
\hline $\begin{array}{l}\text { 35-DO-83 (Umpqual } \\
\text { Eden) }\end{array}$ & 3000-Historic & 3 & 1 & Adolescent estimated to be about 3 months old & Lyman (1988) \\
\hline \multicolumn{6}{|l|}{ Washington } \\
\hline 45-CA-22 (Neah Bay) & Historic & 1 & 1 & $\begin{array}{l}\text { Ethnographically described village. Elephant seals limited } \\
\text { in assemblage }\end{array}$ & Friedman (1976) \\
\hline 45-CA-2I (Hoko River) & $1200-300$ & I & 1 & $\begin{array}{l}\text { Dominated by northern fur seals with elephant seals } \\
<1 \% \text { of assemblage }\end{array}$ & Wigen (2005) \\
\hline 45-CA-25 (Sooes) & 1070-Historic & I & 1 & $\begin{array}{l}\text { Ethnographically named village. Elephant seals limited in } \\
\text { assemblage }\end{array}$ & Friedman (1976) \\
\hline $\begin{array}{l}\text { 45-CA-204 } \\
\text { (Warmhouse) }\end{array}$ & Historic & 1 & 1 & Elephant seals limited in assemblage & Friedman (1976) \\
\hline 45-CA-207 (Tatoosh) & 930-Historic & 2 & 2 & $\begin{array}{l}\text { Ethnographically known site on small island. Elephant } \\
\text { seals limited in assemblage }\end{array}$ & Friedman (1976) \\
\hline 45-CA-24 (Ozette) & $450-430$ & 2 & - & $\begin{array}{l}<1 \% \text { of total pinniped NISP; assemblage dominated by } \\
\text { northern fur seals }\end{array}$ & $\begin{array}{l}\text { Etnier (2007); Huelsbeck } \\
\text { (1994) }\end{array}$ \\
\hline 45-GH-I5 (Minard) & $950-300$ & I & 1 & Possible northern elephant seal bone & $\begin{array}{l}\text { Fancher (200I); Moss and } \\
\text { Losey (20II) }\end{array}$ \\
\hline \multicolumn{6}{|l|}{ British Columbia } \\
\hline DfSI-5 (Ma’acoah) & $1200-300$ & I & 1 & $\begin{array}{l}\text { Dominated by northern fur seals with elephant seals } \\
\text { making up }<1 \%\end{array}$ & Monks (2006) \\
\hline $\begin{array}{l}\text { DfSI-16 (Ts'ishaa, } \\
\text { Benson Island) }\end{array}$ & $1870-250$ & I & 1 & $\begin{array}{l}\text { Probable elephant seal bone. }<1 \% \text { of pinniped assemblage } \\
\text { dominated by northern fur seal }\end{array}$ & McMillan and St Claire (2005) \\
\hline $\begin{array}{l}\text { DiSO-I (Hesquiat } \\
\text { Harbor,Vancouver } \\
\text { Island) }\end{array}$ & $650-500$ & I & 1 & Possible phalanx tentatively identified as an adult female & Calvert (1980) \\
\hline
\end{tabular}

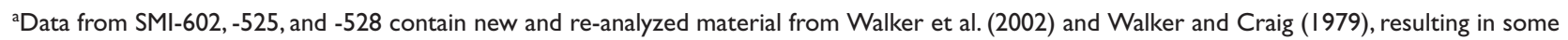
differences in total counts and MNI.The NISP from SMI-525 includes four bones and two individuals identified by Walker, Kennett, and DeLong, and 13 bones and three MNI from our re-analysis of Walker and Craig's (1979) materials. A single elephant seal bone listed from Mendocino County, California (Hildebrandt and Jones, 1992) has been re-identified as a different species.

${ }^{b} \mathrm{MNI}$ is minimum number of individuals estimates calculated by totaling up the number of non-repetitive elements for a given site or unit (see Lyman,

2008). MNI are presented here for future work that may use this measure. 


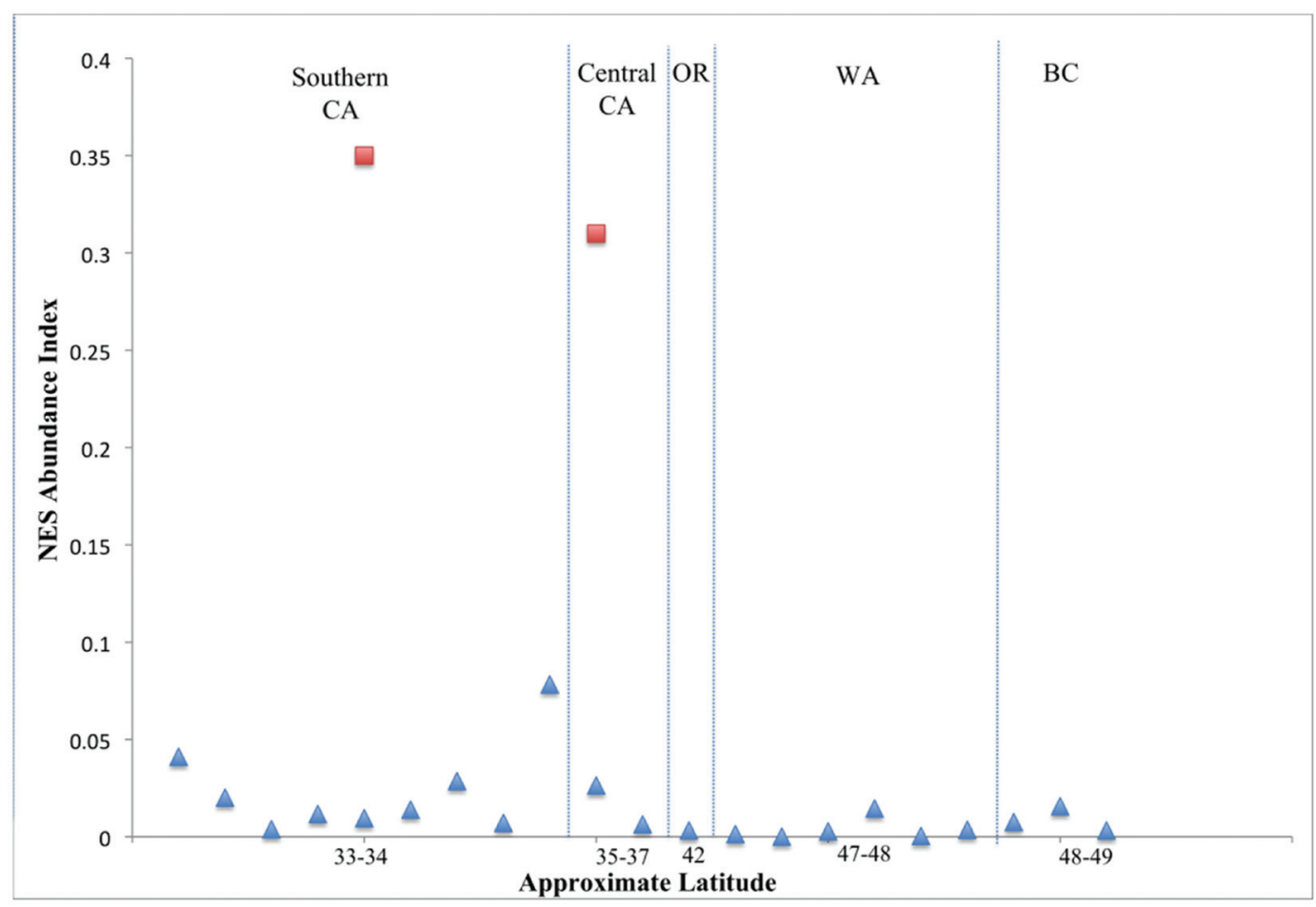

Figure 2. Abundance index of ancient and modern NES by approximate latitude. Values are between 0 and I where I is the highest possible abundance. Archaeological sites noted with a triangle. San Miguel Island (left) and California stock (right) population abundance noted with a square. CA, California; OR, Oregon; WA, Washington; and BC, British Columbia

$28^{\circ} \mathrm{N}$ to $49^{\circ} \mathrm{N}$ latitude (Figure 2) (see also Lyman, 2011). Roughly $85 \%$ of the NES bones identified from Pacific Coast archaeological sites come from between $\sim 33^{\circ}$ and $35^{\circ} \mathrm{N}$, but most of these are from the Channel Islands. Although the Channel Islands contain the most archaeological sites in western North America with NES bones and large modern breeding colonies, NES are extremely rare in archaeological assemblages, generally making up only about $0.7-7.8 \%$ of the total identified pinniped NISP and always ranking much lower than other pinnipeds. The highest percentage is recorded at CA-SMI-602 (located within the huge contemporary Point Bennett rookery), where they are significantly outnumbered by remains of Guadalupe fur seals and California sea lions (Zalophus californianus) (Walker et al., 2002). In contrast to these archaeological data, DeLong and Melin (2002) noted that in 1997 some 50000 NES were present on San Miguel Island, second only to California sea lions at $\sim 80000$.

On the central California coast, where there are currently four substantial rookeries, a single NES specimen is reported from each of two sites, CA-SMA-18 and CA-SLO-2. Extensive excavations at a site immediately adjacent to the largest modern rookery on the mainland at Piedras Blancas failed to produce a single NES specimen (Jones and Ferneau, 2002); where California sea lions instead dominate the archaeological pinniped assemblage. At sites currently being damaged by NES breeding activities at Point Año Nuevo, excavations produced dozens of northern fur seal bones, but just one NES bone (Gifford-Gonzalez and Sunseri, 2009; Hildebrandt et al., 2006; Hylkema, 1991).

The majority of NES specimens come from late-Holocene (3500 yr ago-present) sites. This includes all sites from mainland California, Oregon, Washington and British Columbia, and nine from the Channel Islands. The oldest specimens may come from San Nicolas Island where 14 bones from CA-SNI-11 were reported from a large, multi-component site dated between about 7000 and 500 cal. BP (Bleitz, 1993). Two specimens from CA-SMI-481 come from a discrete component securely dated to $\sim 6000$ years ago (Vellanoweth et al., 2006). Specimens from CA-SCAI-17, CA-ANI-8, and CA-SMI-492 may also be middle Holocene in age, but could date to the late Holocene. Collectively, these data suggest sporadic human exploitation of NES for at least 6000 years, with most evidence from sites dated to the last 1500 years.

Eleven of 28 sites had age at death or sex data reported. On Isla Cedros, the single bone is from a juvenile of unknown sex. Seven sites from the Channel Islands produced sex and/or age at death data. These include a juvenile female from CA-ANI- 8 , a pup from CA-SCRI-240, two adult females from CA-SMI-481, five immature individuals, including at least four males and one female from CA-SMI-525, a possible adult female from CASMI-528, and two juveniles, one of which is 1-2 years old, a pup, and an immature specimen less than 1 year old from CA-SMI-602. Six fragmentary NES bones from CA-SCLI-43B are difficult to age or sex, but include a juvenile and either an adult female or juvenile male. The bones of seven adults and 14 juveniles were recovered from CA-VEN-11, but no sex data were reported. At Oregon's 35-DO-83, all three bones are thought to be from an approximately three-month-old animal. Finally, Calvert (1980) tentatively identified the DiSO-1 specimen from Vancouver Island as an adult female. These data suggest that Native Americans exploited primarily juveniles and smaller numbers of adult females, but no adult males. Although two pups are represented, the data are too few to be certain whether or not breeding colonies were exploited, but if they were, the small number of archaeological bones suggests they were likely small in size and limited in distribution.

The high incidence of juveniles (75\%) raises the possibility that Native Americans exploited mostly stranded NES. Colegrove et al. (2005) found that between 1992 and 2001, 1277 NES stranded on beaches in central California, of which 420 died or were euthanized. Of these, $99 \%(n=1266)$ were pre-weaned pups, 
molted weanlings, and yearlings, with just six subadults and five adults. Malnutrition, disease, and human intervention were the primary causes of strandings. Native Americans probably harvested some stranded NES, but given the vulnerability of younger animals we would also expect a high proportion of young animals if they were actively hunted. Regardless of whether they were scavenged, hunted, or both, the data provide a proxy of the relative abundance of NES in the area.

\section{Discussion and conclusion}

Archaeological NES data document geographic distributions similar to modern populations, but substantial differences with contemporary NES abundance compared with those of other pinnipeds. North of California the data generally meet our test expectations and are similar to modern times, with very small numbers of ancient NES in Oregon, Washington, and British Columbia. However, the limited occurrence and abundance of NES in California, including absence from most sites located near modern rookeries and low numbers on the Channel Islands, suggest a very different pattern from the modern hyper-abundance of NES in central and southern California. The limited archaeological data available from Baja California, including an apparent absence of prehistoric human occupation on Isla de Guadalupe, currently prevent a comparison of abundance in modern and ancient NES populations in Mexico.

Analysis of ancient and modern NES DNA provides further insight into changes in NES abundance and distribution. With a drastic historic population bottleneck, modern NES show extremely limited genetic diversity. Weber et al. $(2000,2004)$ and Hoelzel et al. (2002) analyzed pre- and post-bottleneck NES samples from modern, late nineteenth century, and late-Holocene archaeological specimens from San Miguel and San Nicolas islands. Not surprising given the historical population decline, the archaeological samples of pre-bottleneck age were more diverse genetically than the post-bottleneck specimens (Hoelzel et al., 2002; Weber et al., 2000, 2004). The contrast between large modern NES populations with very low genetic diversity and ancient populations with apparently lower abundance (at least in areas where they are common today) and higher genetic diversity raises the question: Why are there not more NES bones in California archaeological sites?

Four hypotheses might explain the limited abundance of NES remains in coastal California: (1) preservation bias; (2) human food preferences or hunting capabilities; (3) climatic changes; and (4) human settlement strategies/habitat displacement and predation. The first hypothesis - NES bones are found in low abundance because they preserve poorly compared to other pinnipeds - can be dismissed because 96 bones were found and even juvenile elephant seal bones are large and robust. Did human hunters not pursue elephant seals because they were too large and difficult to capture or the flesh was not palatable? While large male elephant seals may have been difficult to hunt, this is not the case for the much smaller females and young. Ancient peoples also extensively hunted/scavenged other pinnipeds using a variety of technologies, including large California and Steller sea lion males (Lyman, 2003). NES contain rich sources of protein, fat, and oil that would have been attractive to ancient peoples. The Makah in Washington hunted NES possibly incidental to their offshore hunting of northern fur seals and described the NES flesh as good to eat (Cowan and Carl, 1945). Southern elephant seals (M. leoni) were also hunted prehistorically elsewhere in the world (e.g. Tasmania, Bryden et al., 1999). Given these factors, hypothesis (2) seems unlikely.

A third hypothesis is that environmental and climatic variables during the Holocene reduced NES populations. The small number of archaeological specimens and limited chronological resolution make it difficult to identify specific paleoclimatic events that may have influenced NES abundance. While marine climatic conditions during the Holocene were variable, including periodic El Niño events and periods of warmer and colder sea surface temperature than today (Kennett, 2005; Kennett et al., 2007), NES were present during the generally warm period of the middle Holocene, but are most common in the last 1500 years or so when marine climatic conditions were highly variable and include periods of cool and warm water conditions (Kennett and Kennett, 2000). Climatic factors likely influenced the biogeography of ancient NES populations, but there are no clear correlations in the Holocene climatic or archaeological data that point to climate as the primary reason for the dearth of NES bones in archaeological sites.

The fourth hypothesis is that Native American settlement and possibly predation by large carnivores influenced the ancient abundance and distribution of NES, especially in coastal California, resulting in the displacement of NES from many of their favored habitats. As humans colonized the Pacific Coast, including the California Channel Islands by about 13000 calendar years ago (Erlandson et al., 2008), they likely found an abundance of pinnipeds, including NES, particularly on offshore islands where they were protected from predation by bears and other large terrestrial predators (Erlandson et al., 1998: 165). Native American occupation or settlement near or on current haul-outs and rookeries, the presence of Native American dogs, and possibly direct predation may have displaced NES from their preferred habitats and driven them to haul-out, breed, and give birth to their young elsewhere. One important variable that affects NES differently than otariids (which often haul-out on rocky shores) is their reliance on sandy beaches, and to a lesser extent gravel or cobble beaches, for haul-outs and rookeries. Many of the primary beaches used by NES as breeding sites today also have archaeological sites nearby. The presence of Native American peoples near these preferred beaches - especially during the late Holocene when human populations were relatively high - would have likely driven NES to increasingly remote pocket beaches and islands without human occupation. In contrast, otariids had options for using nearby offshore rocks and more extensive isolated rocky shores not utilized by NES. Isla de Guadalupe, the Farallones, and possibly other isolated and difficult-to-access islands or coves may have provided ancient refugia for breeding, birthing, and molting. These islands and pocket beaches may have allowed NES populations to remain viable throughout the Holocene, acting as a source of animals that would swim northward to forage as they do today and maintain the genetic diversity seen in prehistoric samples.

Hypothesis four is the best supported by the current archaeological and contemporary NES data. Given the small sample of NES bones currently available, however, questions remain about the effects of ancient human activities and predation, as well as environmental variables on NES, leaving important avenues for further research.

The current abundance and distribution of breeding NES is a testament to their resilience, persistence, and adaptability in the wake of millennia of interactions with Native Americans 
and the onslaught of Euro-American hunters during the eighteenth and nineteenth century fur and oil trade. In the absence of human predation, these animals appear to do exceptionally well and to maintain fitness despite low genetic diversity (Weber et al., 2004). The archaeological data presented here suggest that the abundance of Holocene NES in California was considerably different than today. The modern abundance of NES on islands off California may provide a glimpse of what their populations were like during the Pleistocene prior to human arrival, but bears, saber-tooth cats, and other large terrestrial predators may have restricted their distribution and numbers along the mainland coast before humans arrived. In the absence of human disturbance and predation, as well as major disease, climate change, pollution, or food source disruptions, modern NES populations may continue to expand and thrive. We should be cautious in interpreting their current abundance as a natural or ancient phenomena, however, as it appears to be a pattern not seen in portions of the northeastern Pacific for at least 10000 years.

\section{Acknowledgements}

This paper is dedicated to the late Phillip L. Walker, friend, mentor, and colleague, who helped shape our thinking on numerous topics, including ancient interactions between humans and pinnipeds. Our work on the Channel Islands has been supported by Channel Islands National Park, the Western National Parks Association, the National Science Foundation, and our home institutions. Finally, we thank Arlene Rosen and two anonymous reviewers for constructive comments that greatly improved this manuscript.

\section{References}

Anthony AW (1924) The elephant seal off the coast of Santa Cruz Island, California. Journal of Mammalogy 2: 112-113.

Bartholomew GA and Hubbs CL (1960) Population growth and seasonal movement of the northern elephant seal, Mirounga angustirostris. Mammalia 24: 313-324.

Bleitz DE (1993) The prehistoric exploitation of marine mammals and birds at San Nicolas Island, California. In: Hochberg FG (ed.) Third California Islands Symposium: Recent Advances in Research on the California Islands. Santa Barbara Museum of Natural History, 519-536.

Bonnell ML and Selander RK (1972) Elephant seals: Genetic variation and near extinction. Science 184: 908-909.

Braje TJ, Rick TC, Erlandson JM and DeLong RL (2011) Resilience and reorganization: Archaeology and historical ecology of California Channel Island marine mammals. In: Braje TJ and Rick TC (eds) Human Impacts on Seals, Sea Lions, and Sea Otters: Integrating Archaeology and Ecology in the Northeast Pacific. University of California Press, 273-296.

Bryden MM, O'Connor S and Jones R (1999) Archaeological evidence for the extinction of a breeding population of elephant seals on Tasmania in prehistoric times. International Journal of Osteoarchaeology 9: 430-437.

Calvert SG (1980) A cultural analysis of faunal remains from three archaeological sites in Hesquiat Harbor, B.C. Ph.D. dissertation, University of British Columbia.

Campbell RR (1987) Status of the northern elephant seal, Mirounga angustirostris, in Canada. Canadian Field Naturalist 101: 266-270.

Carretta JV, Forney KA, Lowry MS, Barlow J, Baker J, Johnston D et al. (2009) U.S. Pacific Marine Mammal Stock Assessments: 2009. U.S. Department of Commerce, NOAA Technical Memo, NOAA-TM-NMFSSWFSC-453.

Carretta JV, Forney KA, Muto MM, Barlow J, Baker J, Hanson B et al. (2007) U.S. Pacific Marine Mammal Stock Assessments: 2006. U.S. Department of Commerce, NOAA Technical Memo, NOAA-TM-NMFSSWFSC-398.

Colegrove KM, Greig DJ and Gulland FMD (2005) Causes of live strandings of northern elephant seals (Mirounga angustirostris) and Pacific harbor seals (Phoca vitulina) along the central California Coast, 1992-2001. Aquatic Mammals 31: 1-10.

Collins PW, Guthrie DA, Rick TC and Erlandson JM (2005) Analysis of prey remains excavated from an historic bald eagle nest site on San Miguel Island, California. In: Garcelon DK and Schwemm CA (eds) Proceedings of the Sixth California Islands Symposium. Institute for Wildlife Studies and National Park Service, 103-120.

Colten RH (2002) Prehistoric marine mammal hunting in context: Two western North American examples. International Journal of Osteoarchaeology 12: $12-22$.

Cowan IM and Carl GC (1945) The northern elephant seal (Mirounga angustirostris) in British Columbia waters and vicinity. Canadian Field Naturalist 59: 170-171.

DeLong RL and Melin SR (2002) Thirty years of pinniped research at San Miguel Island. In: Browne D, Mitchell K and Chaney H (eds) Proceedings of the Fifth California Islands Symposium. Santa Barbara Museum of Natural History, 401-406.

Des Lauriers MR (2005) Rediscovering Huamalgua, the Island of Fogs: Archaeological and ethnohistoric investigations of Isla Cedros, Baja California, Mexico. Ph.D. dissertation, University of California, Riverside.

Erlandson JM, Moss ML and Des Lauriers M (2008) Living on the edge: Early maritime cultures of the Pacific Coast of North America. Quaternary Science Reviews 27: 2232-2245.

Erlandson JM, Tveskov MA and Byram RS (1998) The development of maritime adaptations on the southern Northwest Coast of North America. Arctic Anthropology 35: 6-22.

Etnier MA (2007) Defining and identifying sustainable harvests of resources: Archaeological examples of pinniped harvests in the northeastern Pacific. Journal for Nature Conservation 15: 196-207.

Fancher JM (2001) An analysis of the Minard (45GH15) faunal assemblage. M.A. thesis, Washington State University.

Friedman E (1976) An archaeological survey of Makah territory: A study in resource utilization. Ph.D. dissertation, Washington State University.

Gallo-Reynoso JP, Le Boeuf BJ, Figueroa-Carranza AL and Maravilla-Chávez MO (2005) Los pinnípedos de Isla Guadalupe. In: Santos del Prado K and Peters E (eds) Isla Guadalupe: Restauración y Conservación. Instituto Nacional de Ecología, 170-201.

Gifford-Gonzalez D and Sunseri CK (2009) An earlier extirpation of fur seals in the Monterey Bay region: Recent findings and social implications. Proceedings of the Society for California Archaeology 21: 89-102.

Gifford-Gonzalez D, Newsome SD, Koch PL, Guilderson TP, Snodgrass JJ and Burton RK (2005) Archaeofaunal insights on pinniped-human interactions in the northeastern Pacific. In: Monks G (ed.) The Exploitation and Cultural Importance of Sea Mammals. Oxbow Books, 19-38.

Gill T (1866) On a new species of the genus Macrorhinus. Proceedings of the Chicago Academy of Sciences 1: 33-34.

Hildebrandt WR and Jones TL (1992) Evolution of marine mammal hunting: A view from the California and Oregon coasts. Journal of Anthropological Archaeology 11: 360-401.

Hildebrandt W and Jones TL (2002) Depletion of prehistoric pinniped populations along the California and Oregon coasts: Were humans the cause? In: Kay C and Simmons RT (eds) Wilderness and Political Ecology: Aboriginal Influences and the Original State of Nature. University of Utah Press, 72-110.

Hildebrandt WR, Farqhuar J and Hylkema MG (2006) Archaeological investigations at CA-SMA-218: A study of prehistoric adaptations at Año Nuevo State Reserve. Report on file, Northwest Archaeological Information Center, Department of Anthropology, Sonoma State University.

Hodder J, Brown R and Cziesla C (1998) The northern elephant seal in Oregon: A pupping range extension and onshore occurrence. Marine Mammal Science 14: 873-881.

Hoelzel AR, Fleischer RC, Campagna C, Le Bouef BJ and Alvord G (2002) Impact of a population bottleneck on symmetry and genetic diversity in the northern elephant seal. Journal of Evolutionary Biology 15: 567-575.

Huelsbeck DR (1994) Mammals and fish in the subsistence economy of Ozette. In: Samuels SR (ed.) Ozette Archaeological Project Research Reports Volume II: Fauna. Washington State University Department of Anthropology Reports of Investigations 66, 17-91.

Hylkema MG (1991) Prehistoric Native American adaptations along the central California Coast of San Mateo and Santa Cruz counties. M.A. thesis, San Jose State University.

Jeffries SJ, Gearin PJ, Huber HR, Saul DL and Pruett DA (2000) Atlas of seal and sea lion haulout sites in Washington. Washington Department of Fish and Wildlife, available at: www.wa.gov.wdfw.

Jones TL and Ferneau J (2002) Prehistory at San Simeon Reef: Archaeological Data Recovery at CA-SLO-179 and -267, San Luis Obispo County, 
California. San Luis Obispo County Archaeological Society Occasional Papers 16.

Jones TL, Porcasi JF, Gaeta J and Codding BF (2008) Diablo Canyon fauna: A coarse-grained record of trans-Holocene foraging from the central California mainland coast. American Antiquity 73: 289-316.

Kennett DJ (2005) The Island Chumash: Behavioral Ecology of a Maritime Society. University of California Press.

Kennett DJ and Kennett JP (2000) Competitive and cooperative responses to climatic instability in southern California. American Antiquity 65: 379-395.

Kennett DJ, Kennett JP, Erlandson JM and Cannariato KG (2007) Human responses to middle Holocene climate change on California's Channel Islands. Quaternary Science Reviews 26: 351-367.

Lyman RL (1988) Zoogeography of Oregon Coast marine mammals: The last 3000 years. Marine Mammal Science 4: 247-264.

Lyman RL (2003) Pinniped behavior, foraging theory, and the depression of metapopulations and nondepression of a local population on the southern Northwest Coast of North America. Journal of Anthropological Archaeology 22: $376-388$.

Lyman RL (2008) Quantitative Paleozoology. Cambridge University Press.

Lyman RL (2011) A history of paleoecological research on sea otters and pinnipeds of the eastern Pacific Rim. In: Braje TJ and Rick TC (eds) Human Impacts on Seals, Sea Lions, and Sea Otters: Integrating Archaeology and Ecology in the Northeast Pacific. University of California Press, 19-40.

Lyon GM (1937) Pinnipeds and a sea otter from the Point Mugu shellmound of California. Publications of the University of California at Los Angeles in Biological Sciences 1: 133-168.

McMillan AD and St Claire DE (2005) Ts 'ishaa: Archaeology and Ethnography of a Nuu-chah-nulth Origin Site in Barkley Sound. Archaeology Press, Department of Archaeology, Simon Fraser University.

Monks GG (2006) The fauna from Ma'acoah (DfSi-5), Vancouver Island, British Columbia: An interpretive summary. Canadian Journal of Archaeology 30: $215-244$.

Moss ML and Losey RJ (2011) Native American use of seals, sea lions and sea otters in estuaries of northern Oregon and southern Washington. In: Braje TJ and Rick TC (eds) Human Impacts on Seals, Sea Lions, and Sea Otters: Integrating Archaeology and Ecology in the Northeast Pacific. University of California Press, 167-195.

Moss ML, Yang D, Newsome SD, Speller CF, McKechnie I, McMillan AD et al. (2006) Historical ecology and biogeography of North Pacific pinnipeds: Isotopes and ancient DNA from three archaeological assemblages. Journal of Island and Coastal Archaeology 1: 165-190.

Newsome SD, Etnier MA, Gifford-Gonzalez D, Phillips DL, Van Tuinen M, Hadly EA et al. (2007) The shifting baseline of northern fur seal ecology in the northeast Pacific Ocean. Proceedings of the National Academy of Sciences 104: 9709-9714.

Porcasi JF (2002) Updating prehistoric maritime subsistence at Little Harbor, Santa Catalina Island, California. In: Browne D, Mitchell K and Chaney H (eds) Proceedings of the Fifth California Islands Symposium. Santa Barbara Museum of Natural History, 580-589.

Porcasi JF, Jones TL and Raab LM (2000) Trans-Holocene marine mammal exploitation on San Clemente Island: A tragedy of the commons revisited. Journal of Anthropological Archaeology 19: 200-220.
Rick TC (2007) The Archaeology and Historical Ecology of Late Holocene San Miguel Island. Cotsen Institute of Archaeology, University of California, Los Angeles.

Rick TC, Delong RL, Erlandson JM, Braje TJ, Jones TL, Kennett DJ et al. (2009) A trans-Holocene archaeological record of Guadalupe fur seals (Arctocephalus townsendi) on the California Coast. Marine Mammal Science 25: 487-502.

Sanderfur E (1978) Appendix 3: Anacapa Island faunal analysis. In: Rozaire C, A Report on the Archaeological Investigations of Three California Channel Islands: Santa Barbara, Anacapa, and San Miguel. Report on file, Department of Anthropology, Natural History Museum of Los Angeles, 187-203.

Scammon CM (1874) The Marine Mammals of the North-western Coast of North America, Described and Illustrated, With an Account of the American Whale-fishery. J.H. Carmony and Co.

Stewart BS and DeLong RL (1995) Double migrations of the northern elephant seal, Mirounga angustirostris. Journal of Mammalogy 79: 196-205.

Stewart BS and Huber HR (1993) Mirounga angustirostris. Mammalian Species 449: 1-10

Stewart BS, Yochem RK, Huber HR, Delong RL, Jameson RJ, Sydeman WJ et al. (1994) History and present status of northern elephant seals. In: Le Bouef B and Laws R (eds) Elephant Seals: Population Ecology, Behavior, and Physiology. University of California Press, 29-48.

Townsend $\mathrm{CH}$ (1885) An account of recent captures of the California sea elephant, and statistics relating to the present abundance of the species. Proceedings of the U.S. National Museum 8: 90-93.

Townsend CH (1912) The northern elephant seal. Zoologica 1: 159-173.

Vellanoweth RL, Rick TC, Erlandson JM and Reynolds G (2006) A 6,000 year old red abalone midden from Otter Point, San Miguel Island, California. North American Archaeologist 27: 69-90.

Walker PL (1978) An Ethnozoological Analysis of Faunal Remains from Four Santa Barbara Channel Island Archaeological Sites. Report on file, Channel Islands National Park.

Walker PL and Craig S (1979) Archaeological evidence concerning the prehistoric abundance of sea mammals at Point Bennett, San Miguel Island. California Fish and Game 65: 50-54.

Walker PL and Snethkamp PE (1984) Archaeological Investigations on San Miguel Island - 1982: Prehistoric Adaptations to the Marine Environment. Report on file, Central Coast Information Center, University of California, Santa Barbara.

Walker PL, Kennett DJ, Jones TL and DeLong RL (2002) Archaeological investigations of the Point Bennett pinniped rookery on San Miguel Island. In: Browne D, Mitchell K and Chaney $\mathrm{H}$ (eds) Proceedings of the Fifth California Islands Symposium. Santa Barbara Museum of Natural History, 628-632.

Weber DS, Stewart BS, Garza JC and Lehman N (2000) An empirical genetic assessment of the severity of the northern elephant seal population bottleneck. Current Biology 10: 1287-1290.

Weber DS, Stewart BS, Schienman J and Lehman N (2004) Major histocompatability complex variation at three class II loci in the northern elephant seal. Molecular Ecology 13: 711-718.

Wigen RJ (2005) Vertebrate fauna. In: Croes DR (ed.) The Hoko River Archaeological Site Complex: The Rockshelter (45CA21), 1000-100 B.P., Olympic Peninsula, Washington. Washington State University Press, 71-104. 